\title{
Activity-Dependent Expression of Acyl-Coenzyme A-Binding Protein in Retinal Muller Glial Cells Evoked by Optokinetic Stimulation
}

\author{
Neal H. Barmack, Timothy R. Bilderback, Henry Liu, Zuyuan Qian, and Vadim Yakhnitsa \\ Neurological Sciences Institute, Oregon Health and Science University, Beaverton, Oregon 97006
}

\begin{abstract}
Long-term horizontal optokinetic stimulation (HOKS) decreases the gain of the horizontal optokinetic reflex and evokes the second phase of optokinetic afternystagmus (OKAN-II). We investigated the possible molecular constituents of this adaptation. We used a differential display reverse transcriptase-PCR screen for mRNAs isolated from retinas of rabbits that received HOKS. In each rabbit, we compared mRNAs from the retina stimulated in the posterior $\rightarrow$ anterior (preferred) direction with mRNAs from the retina stimulated in the anterior $\rightarrow$ posterior (null) direction. Acyl-CoA-binding protein (ACBP) mRNA was one of four mRNAs selected by this screen, the proteins of which interact with GABA receptors. HOKS in the preferred direction increased ACBP mRNA transcription and ACBP protein expression. ACBP was localized to Muller glial cells by hybridization histochemistry and by immunohistochemistry. ACBP interacts with the $\alpha_{1}$-subunit of the $\mathrm{GABA}_{\mathrm{A}}$ receptor, as determined by a yeast two-hybrid technique. This interaction was confirmed by coimmunoprecipitation of ACBP and the $\alpha_{1}$-subunit of the $\mathrm{GABA}_{\mathrm{A}}$ receptor using an antibody to $\mathrm{GABA}_{\mathrm{A}} \alpha_{1}$. The interaction was also confirmed by a "pull-down" assay in which histidine-tagged ACBP was used to pull down the $\mathrm{GABA}_{\mathrm{A}} \alpha_{1}$. ACBP does not cross the blood-brain barrier. However, smaller truncated proteolytic fragments of ACBP do, increasing the excitability of central cortical neurons.

Muller cells may secrete $\mathrm{ACBP}$ in the inner plexiform layer, thereby decreasing the sensitivity of $\mathrm{GABA}_{\mathrm{A}}$ receptors expressed on the surface of ganglion cell dendrites. Because retinal directional sensitivity is linked to GABAergic transmission, HOKS-induced expression of ACBP could provide a molecular basis for adaptation to HOKS and for the genesis of OKAN-II.
\end{abstract}

Key words: adaptation; astrocyte (astroglia); diazepam; glia; nystagmus; retina

\section{Introduction}

The horizontal optokinetic reflex (HOKR) is adaptive. It is evoked by rotation of a cylindrical optokinetic drum about a vertical axis and consists of conjugate, horizontal, compensatory eye movements interspersed with anticompensatory fast phases. In rabbits, if horizontal optokinetic stimulation (HOKS) is stopped after $1 \mathrm{hr}$, the first phase of optokinetic afternystagmus (OKAN-I) persists, in which conjugate eye movements continue in the same direction of the former HOKS for $\sim 0.5-5 \mathrm{~min}$.

Prolonged HOKS (12-48 hr) progressively reduces the gain of the HOKR (Fig. $1 E$ ). When HOKS stops, an afternystagmus, OKAN-II, develops in which the eyes move oppositely to the direction of the former HOKS (Fig. 1D). OKAN-II lasts for tens of hours (Barmack and Nelson, 1987; Pettorossi et al., 1999; Bar-

\footnotetext{
Received Nov. 20, 2003; Revised Nov. 20, 2003; Accepted Nov. 21, 2003.

This work was supported by National Eye Institute Grant EY 04778. We gratefully acknowledge the histological expertise of Mary Westcott. We thank Drs. A. J. Tobin and N. Tillakaratne (Brain Research Institute, University of California, Los Angeles, Los Angeles, (A) for the gift of the $\alpha_{1}$-subunit of the $G_{A B A_{A}}$ receptor. We also thank Dr. S Hollenberg (Vollum Institute, Oregon Health and Science University, Portland, OR) for his help in establishing a yeast two-hybrid protocol.

Correspondence should be addressed to Dr. Neal H. Barmack, Neurological Sciences Institute, Oregon Health and Science University, West Campus, 505 Northwest 185th Avenue, Beaverton, 0R 97006. E-mail: barmackn@ohsu.edu.

DOI:10.1523/JNEUROSCI.3936-03.2004

Copyright $\odot$ 2004 Society for Neuroscience $\quad 0270-6474 / 04 / 241023-11 \$ 15.00 / 0$
}

mack et al., 2002). The reduction in gain of the HOKR and the genesis of OKAN-II are the hallmarks of optokinetic adaptation.

During binocular HOKS, one eye is stimulated in the preferred posterior $\rightarrow$ anterior direction, increasing the discharge of $\mathrm{ON}$ - and ON-OFF direction selective ganglion cells (DSGCs), whereas the opposite eye is stimulated in the null, anterior $\rightarrow$ posterior direction. DSGCs have large receptive fields and are concentrated at highest densities in the visual streak. The visual streak lies just below and parallel to retinal vessels and myelinated nerve fibers that extend horizontally from the optic nerve head (Hughes, 1971; Choudhury, 1981). DSGCs are sensitive to stimulus velocities of $0.1-10^{\circ} / \mathrm{sec}$ and respond to light-dark edges (Collewijn, 1975; Oyster et al., 1980; Simpson et al., 1988; Soodak and Simpson, 1988).

GABAergic pathways are most clearly linked to direction selectivity. Asymmetric release of GABA by amacrine cell axon terminals on ganglion cell dendrites during stimulation in the preferred and null directions could account for directional selectivity (Barlow and Levick, 1965; Euler et al., 2002; Fried et al., 2002). A role for $\mathrm{GABA}_{\mathrm{A}}$ receptors in direction selectivity is suggested by the observation that null responses of DSGCs in retinal eye cups are abolished by perfusion with $\mathrm{GABA}_{\mathrm{A}}$-specific antagonists (Kittila and Massey, 1995, 1997).

Horizontal DSGCs project centrally to the contralateral nucleus of the optic tract (NOT), one of the nuclei of the accessory optic system (Giolli et al., 1985, 1988). NOT cells project to ipsi- 
A

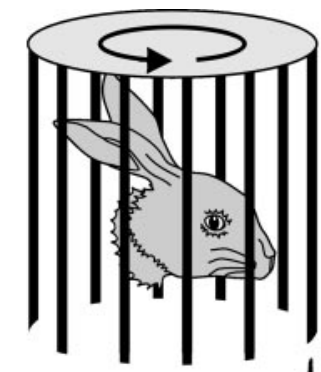

B

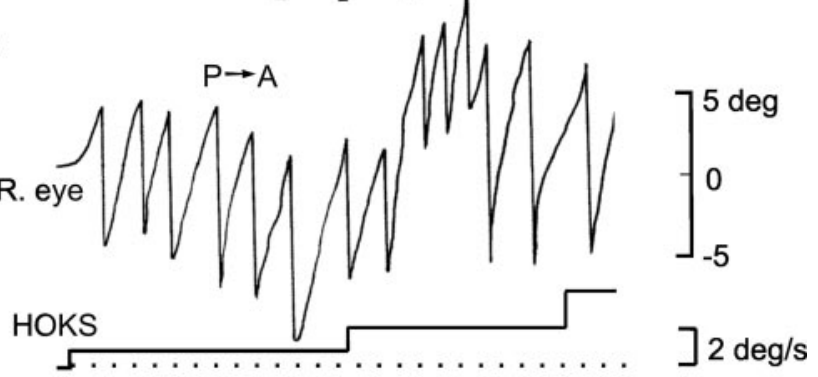

C

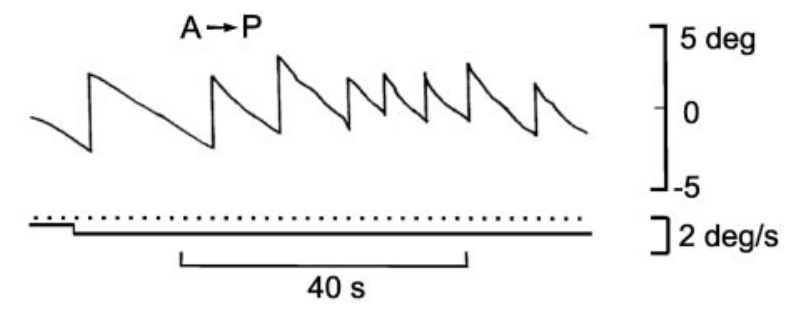

D

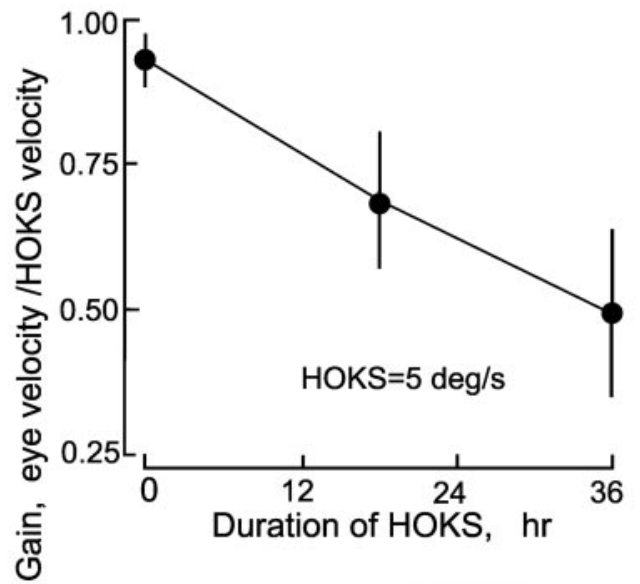

$E$

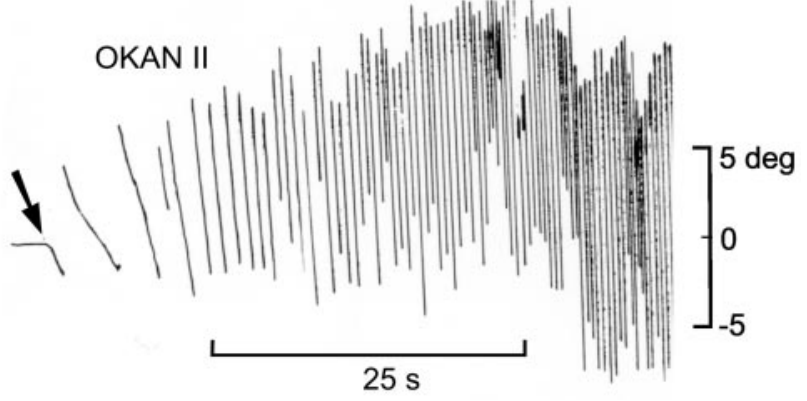

Figure 1. Long-term HOKS decreases gain of the HOKR and evokes OKAN-II. A, Rotation of the optokinetic drum about a vertical axis evokes HOKR. B, Monocular HOKS in preferred direction $\left(5^{\circ} / \mathrm{sec}\right)$ evokes a conjugate HOKR at high gain. $C$, Monocular HOKS in the null direction evokes lower-gain HOKR. D, Gain of the HOKR decreases with increasing duration of HOKS. $E$, After $18-24 \mathrm{hr}$ of binocular HOKS, OKAN-II is evoked when HOKS is stopped and the rabbit is placed in total darkness (indicated by the arrow). Note that the slow phase of the evoked OKAN-II is reversed with respect to the slow phase of the HOKR. R, Right; $P \rightarrow A$, posterior $\rightarrow$ anterior; $A \rightarrow P$, anterior $\rightarrow$ posterior. lateral cells in the nucleus tegmenti pontis, dorsal cap of the inferior olive, pontine nuclei, dorsal lateral geniculate nucleus, medial vestibular nucleus, and nucleus prepositus hypoglossi (Terasawa et al., 1979; Mustari et al., 1994; Schmidt et al., 1995). The axons of dorsal cap neurons, climbing fibers, project to Purkinje cells in the contralateral flocculus and nodulus of the cerebellum (Alley et al., 1975). Floccular and nodular Purkinje cell axon terminals synapse on cells in the subjacent vestibular nuclei, which in turn have direct and indirect projections onto horizontal oculomotor neurons. Adaptation to HOKS could occur at one or several sites in this circuitry.

Although optokinetic circuitry is known, little is understood about how this circuitry adapts to prolonged HOKS. We used differential display reverse transcriptase (DDRT)-PCR to screen different parts of the circuitry for mRNAs, the transcription of which is differentially affected by long-term HOKS. In the retina, four transcripts related to GABAergic synaptic function were identified by DDRT-PCR. One of these was a transcript for acylCoA-binding protein (ACBP), a protein with increased expression in Muller glial cells during HOKS in the preferred direction.

\section{Materials and Methods}

Anesthesia and surgery. In preparatory operations, pigmented rabbits were anesthetized with intramuscular injections of ketamine hydrochloride $(50 \mathrm{mg} / \mathrm{kg})$, xylazine $(6 \mathrm{mg} / \mathrm{kg})$, and acepromazine maleate $(1.2$ $\mathrm{mg} / \mathrm{kg}$ ). The head of each rabbit was aligned in a stereotaxic apparatus. Under aseptic surgical conditions, a $2 \mathrm{~cm}$ midline incision on the dorsal surface of the cranium was made. The periosteum was removed. Two stainless-steel screws $(8-32)$ were anchored to the calvarium with four smaller peripherally placed stainless-steel screws (2-56) and dental cement. The two larger screws mated with devices to restrain head movement during optokinetic stimulation. Rabbits were housed and handled according to the guidelines of the National Institutes of Health on the use of experimental animals. All animal procedures were reviewed and approved by the Institutional Animal Care and Use Committee of the Oregon Health and Science University.

Long-term binocular HOKS. Rabbits were placed in a restrainer at the center of a cylindrical optokinetic drum with a contour-rich pattern on the interior wall (diameter, $110 \mathrm{~cm}$; height, $115 \mathrm{~cm}$ ). The head of the rabbit was fixed to the restrainer by a spring-loaded coupling that mated with implanted head screws. The coupling maintained a head pitch angle of $12^{\circ}$ with respect to earth horizontal. This angle corresponds to that maintained by unrestrained rabbits and aligns the visual streak and the horizontal semicircular canals in the horizontal plane (Hughes, 1971; Barmack and Nelson, 1987; Soodak and Simpson, 1988). The head coupling permitted small movements in the sagittal plane but prevented head movements in the horizontal plane. This method of restraint caused no pressure on any part of the body. The rabbit maintained its normal posture. All four paws remained in contact with the support surface.

The optokinetic drum was rotated at $5 \% \mathrm{sec}$, stimulating the left eye of the restrained rabbit in the posterior $\rightarrow$ anterior direction and the right eye in the anterior $\rightarrow$ posterior direction. Optokinetic stimulation lasted $48 \mathrm{hr}$. Every $8 \mathrm{hr}$, the rabbit was removed from the drum and allowed access to food and water under ambient illumination reduced by the opaque roof of the feeding cage. When the optokinetic stimulation was stopped, the rabbit was immediately anesthetized (see above), and the left and right retinas were removed.

The efficacy of long-term HOKS in evoking differential changes in retinal gene transcription was inferred from previous experiments in which identical long-term HOKS evoked changes in the expression of corticotropin-releasing factor mRNA in neurons in the dorsal cap of the inferior olive (Barmack and Young, 1990). Dorsal cap neurons receive direction-selective inputs from the nucleus of the optic tract. NOT neurons receive projections from ON-DSGCs in the contralateral eye. Changes in relative transcription levels of dorsal cap neurons are detected after only $6 \mathrm{hr}$ of HOKS and reach a sevenfold difference after $48 \mathrm{hr}$ of HOKS. 
DDRT-PCR. We used a modification of the DDRT-PCR technique (Liang and Pardee, 1992) in which 12 $3^{\prime}$-oligo-dT anchored primers and four $5^{\prime}$-arbitrary primers were used to reverse transcribe mRNA to cDNA and to further amplify cDNA for gel analysis. Each of the anchored 3 '-primers had two non-dT bases attached to a poly-T tail. This facilitated priming and first-strand cDNA synthesis from different subpopulations of the mRNA pool. Anchored 3'-primers were 31 bases long, including a 17 mer T7 phage promoter sequence upstream of a 12 mer oligo-dT region. Each of the $5^{\prime}$-arbitrary primers included an M13 promoter. First-strand fragments were converted into one, or at most a few, different double-stranded cDNA fragments during subsequent DDRTPCR amplification using different upstream arbitrary $5^{\prime}$-primers.

Rectangular retinal tissue samples $(2 \times 15 \mathrm{~mm})$ were removed and included the visual streak of each retina. The samples were frozen in isopentane cooled by dry ice. The tissue was homogenized in a Trizol (Invitrogen, Gaithersburg, $\mathrm{MD}$ ) solution. RNA samples had an $\mathrm{A}_{260 / 280}$ ratio $\geq 1.8$.

First-strand synthesis of cDNA was done with $0.2 \mu \mathrm{g}$ of DNase-treated total RNA using avian myeloblastosis virus reverse transcriptase (Invitrogen) in the presence of 12 different oligo-dT anchored primers and $20 \mu \mathrm{M}$ deoxy-NTP for $1 \mathrm{hr}$ at $42^{\circ} \mathrm{C}$. After heat inactivation of reverse transcriptase at $95^{\circ} \mathrm{C}$ for $5 \mathrm{~min}, \mathrm{PCR}$ amplification was performed in the presence of $\left[{ }^{33} \mathrm{P}-\alpha\right]$ deoxy-ATP (dATP) (PerkinElmer Life Sciences, Emeryville, CA) using TaqDNA polymerase (Invitrogen).

Amplified cDNA was separated on a $4.5 \%$ polyacrylamide denaturing gel. The dried gel was exposed to BioMax MR film (Eastman Kodak, Rochester, NY) for 1-2 d. Identified cDNA fragments were recovered and reamplified by PCR using the appropriate corresponding set of primers. The reamplified cDNA was separated by agarose gel electrophoresis. It was purified using a Geneclean II kit (BIO 101, Vista, CA) and cloned into the pT7Blue vector (Novagen, Madison, WI). Plasmid DNA was prepared, and the insert was used as a probe for Northern blots and for cDNA library screening.

DNA sequencing: library screening and extension of DDRT-PCR gene fragments. A rabbit brain $5^{\prime}$-stretch plus cDNA library (Clontech, Palo Alto, CA) was used to obtain longer sequences from DDRT-PCR gene fragments cloned into a pT7Blue vector. Positive plaques were rescued into the plasmid vector Bluescript SK ${ }^{-}$. The inserts were sequenced using a thermosequenase radiolabeled terminator cycle sequencing kit (United States Biochemicals, Cleveland, OH). A GeneRacer Kit (Invitrogen) was also used to obtain complete gene sequences.

Northern blots. Total RNA was isolated with Trizol (Invitrogen) from retinal tissue samples weighing 15-20 mg. Equal amounts of mRNA were separated on agarose gels $(1.2 \%)$, transferred onto nylon membranes (MSI, Westboro, MA) with $20 \times$ SSPE (in M: $3 \mathrm{NaCl}, 0.02 \mathrm{EDTA}$, and 0.25 $\mathrm{NaH}_{3} \mathrm{PO}_{4}, \mathrm{pH}$ 7.4) for $12 \mathrm{hr}$, and then fixed by exposure to ultraviolet light. The membrane was hybridized with a probe containing the gene of interest generated from a plasmid and labeled with a ${ }^{32} \mathrm{P}$ deoxy-CTP kit (Amersham Biosciences, Piscataway, NJ). The nylon membrane was prehybridized for $6 \mathrm{hr}$ at $42^{\circ} \mathrm{C}$ using prehybridization solution (Orbach et al., 1990). Hybridization was conducted by adding labeled oligonucleotide probes to the prehybridization solution $\left(\sim 1.8 \times 10^{6} \mathrm{cpm} / \mathrm{ml}\right)$. Hybridization was performed overnight at $42^{\circ} \mathrm{C}$. The nitrocellulose membrane was washed twice for $15 \mathrm{~min}$ with $0.02 \times$ SSPE in $0.5 \%$ SDS at room temperature and once for $15 \mathrm{~min}$ at $65^{\circ} \mathrm{C}$. The membrane was exposed to $\mathrm{x}$-ray film (X-Omat AR; Eastman Kodak) at $-80^{\circ} \mathrm{C}$ with an intensifying screen for $2 \mathrm{~d}$.

Hybridization histochemistry. Fresh frozen tissue sections were cut 14 $\mu \mathrm{m}$ thick and thaw mounted onto slides (Barmack and Young, 1990). Oligonucleotide probes were end labeled with $\left[{ }^{33} \mathrm{P}-\alpha\right]$ dATP (PerkinElmer Life Sciences) and purified with a Princeton Spin 20 separation column. Each probe had an activity of $40-60,000 \mathrm{cpm} / \mu \mathrm{l}$. After hybridization, the sections were exposed to an x-ray film (Amersham Biosciences) for $24 \mathrm{hr}$. On the basis of the results of this initial x-ray film exposure, sections were coated with NTB2 nuclear emulsion (Eastman Kodak) and exposed for 6-9 d. After development of the nuclear emulsion, sections were counterstained through the emulsion with neutral red.

Preparation of ACBP antibody. A bacterial expression system (TOPO TA expression kit; Invitrogen) generated sufficient amounts of ACBP to immunize chickens and goats. The correct expression sequence of ACBP was confirmed by $\mathrm{N}$-terminal protein sequence analysis performed on an $\mathrm{N}$-terminal protein sequencer (model 492; Applied Biosystems, Foster City, CA) using N-terminal Edman degradation chemistry. These antibodies were affinity purified and used for immunolabeling Western blots and for immunohistochemistry.

Preparation of retinal subfractions. After dissection, the central retina was immediately homogenized with a $10 \times$ volume of Tris-buffered saline (TBS) (in mм: 20 Tris- $\mathrm{HCl}$ and $150 \mathrm{NaCl}, \mathrm{pH} 7.5$ ). To TBS was added $1 \mathrm{~mm}$ EGTA, $1 \mathrm{~mm}$ phenylmethylsulfonyl fluoride, $10 \mu \mathrm{g} / \mathrm{ml}$ aprotinin, and $10 \mu \mathrm{g} / \mathrm{ml}$ leupeptin. All subsequent procedures were performed at $4^{\circ} \mathrm{C}$. The homogenate was centrifuged at $14,000 \mathrm{rpm}$ for $10 \mathrm{~min}$. The supernatant contained the cytosolic fraction. The remaining pellet was sonicated for $30 \mathrm{sec}$ in TBS containing 2\% SDS. After centrifugation at $14,000 \mathrm{rpm}$ for $10 \mathrm{~min}$, the supernatant contained the membraneassociated fraction.

Gel electrophoresis and immunoblotting. Proteins from different cell fractions were separated either on a $15 \%$ SDS-PAGE gel or on a $12.5 \%$ urea gel (Laemmli, 1970). After electrophoresis, proteins were transferred onto Immobilon-P-membranes, blocked with PBS Tween 20 (PBST) containing 5\% milk, incubated with primary antibody in PBST, and visualized with horseradish peroxidase-conjugated anti-goat IgG using enhanced chemiluminescence (Amersham Biosciences).

Immunocytochemistry. Retinas were fixed by a $1 \mathrm{hr}$ perfusion in freshly depolymerized $4 \%$ paraformaldehyde and $0.15 \%$ saturated picric acid in $0.1 \mathrm{~m}$ PBS, $\mathrm{pH} 7.2$, at room temperature. The neural retina was removed and postfixed for $20 \mathrm{~min}$. The retina was then rinsed in PBS and dehydrated in graded sucrose (10-30\%) in $0.1 \mathrm{M} \mathrm{PBS,} \mathrm{pH} \mathrm{7.4,} \mathrm{before} \mathrm{being}$ frozen, sectioned on a cryostat at $10-14 \mu \mathrm{m}$, and thaw mounted. Tissue sections were incubated on the slide with the primary antibody and developed with a double peroxidase antiperoxidase protocol.

Yeast two-hybrid system for identification of protein interaction. A yeast two-hybrid method detected protein-protein interactions, specifically interactions between ACBP and the $\alpha_{1}$-subunit of the GABA receptor. The yeast two-hybrid method uses the relative separation of the activation domain $(\mathrm{AD})$ and binding domain $(\mathrm{BD})$ of a reporter gene to indicate protein interaction. Attached to separate proteins that interact, the two domains are brought into close proximity, and transcription of the reporter gene occurs. Attached to separate proteins that do not interact, the domains will remain distant and transcription does not occur. Transcription in the reporter gene leads to a visually detectable signal. In the present experiment, activation and binding domains were coupled to the transcription of a reporter gene that expressed $\beta$-galactosidase (Chien et al., 1991).

Immunoprecipitation of ACBP from rabbit brain lysates with antibody to $G A B A_{A} \alpha 1$. Lysates of rabbit brain were prepared by sonication three times for $15 \mathrm{sec}$ in a lysis buffer $(20 \mathrm{~mm}$ Tris- $\mathrm{HCl}, \mathrm{pH} 7.5,150 \mathrm{~mm} \mathrm{NaCl}$, $1 \mathrm{~mm}$ EGTA, 0.25\% Igepal, plus a Complete protease inhibitor mixture tablet for each $15 \mathrm{ml}$ of buffer) (Roche, Branchburg, NJ). The lysates were centrifuged at $12,000 \times g$ for $10 \mathrm{~min}$ at $4^{\circ} \mathrm{C}$ to remove insoluble debris. The supernatant was precleared with protein A/G plus agarose beads (Santa Cruz Biotechnology, Santa Cruz, CA) to remove proteins that bind nonspecifically to the beads. The beads were removed by centrifugation at $2000 \times g$. The cleared lysates were incubated with $4 \mu \mathrm{g}$ of polyclonal antibody to $\mathrm{GABA}_{\mathrm{A}} \alpha_{1}$ for $2 \mathrm{hr}$ at $4^{\circ} \mathrm{C}$. The $\mathrm{A} / \mathrm{G}$ plus agarose beads were then added to the mixture for $1 \mathrm{hr}$. The beads were removed by centrifugation at $200 \times g$ and washed three times with lysis buffer. The immunoprecipitate was boiled for $10 \mathrm{~min}$ to dissociate the proteins immunoprecipitated with the beads. The dissociated solution was run subsequently on a $10 \%$ SDS-PAGE gel.

Protein "pull-down" assay using histidine-tagged ACBP. QNR/K2 cells were transfected with the PCDNA 3.1 expression vector containing the histidine-tagged ACBP gene. Expressed ACBP was purified using nickelimpregnated agarose beads (Ni-NTA; Qiagen, Hilden, Germany). The beads were poured into a column and washed with three column volumes of low imidazole-containing buffer $(20 \mathrm{~mm}$ imidazole in $50 \mathrm{~mm}$ $\mathrm{Na}_{2} \mathrm{PO}_{4}, \mathrm{pH}$ 8.0, $300 \mathrm{~mm} \mathrm{NaCl}$ ). The washed beads were incubated with rabbit brain lysate. Proteins pulled down by ACBP were removed from 
Table 1. Gene products, identified by DDRT-PCR after long-term optokinetic stimulation

\begin{tabular}{ll}
\hline Gene fragments & Primers \\
\hline Acyl-CoA-binding protein & 4 \\
Tumor necrosis factor (TNF) receptor-associated factor-TNF receptor-associated & \\
$\quad$ protein & 1 \\
Cytochrome c oxidase subunit Vic & 1 \\
Light intermediate chain-2 dynein & 1 \\
Recoverin & 1 \\
Mitochondrial protein & 4 \\
GABA receptor-associated protein & 2 \\
TATA box binding protein & 2 \\
Bicarbonate cotransporter & 2 \\
14-3-3- $\varepsilon$ protein & 2 \\
14-3-3- $\theta$ protein & 2 \\
P55-related membrane-associated guanylate kinase-like protein & 2
\end{tabular}

Each of these gene products was elevated in the retina of the eye stimulated in the preferred direction, relative to those in the retina of the eye stimulated in the null direction. The number of different primer pairs out of the 48 combinations of "anchored" (12) and "arbitrary" (4) primers that identified a differentially transcribed gene product is listed in the right column.

the beads and separated from ACBP with a wash of $250 \mathrm{~mm}$ imidazole buffer.

Fixation of the head and implantation of EEG electrodes. Ten pigmented rabbits were anesthetized with a ketamine mixture as described above and fitted with head-restraint screws. Two EEG electrodes made from 30 gauge nichrome wire were inserted into the posterior cortex. One of the implanted anchor screws was used as a recording reference electrode.

Intravenous and intracisternal injection of ACBP. Previously implanted stainless screws were mated with a bar used to support the head in a three-axis vestibular rate table. During vestibular stimulation, the body of the rabbit was encased in foam rubber and fixed with elastic straps to a plastic tube aligned with the longitudinal axis of the rate table. ACBP was administered intravenously through a 22 gauge intravenous cannula placed in the marginal ear vein. Intravenous injections were $0.5 \mathrm{ml} \mathrm{(1-2}$ $\mathrm{mg} / \mathrm{ml}$ ) administered over an interval of 30-60 sec. Control injections of vehicle alone were made before ACBP injections.

Intracisternal injections of ACBP were made in lightly anesthetized rabbits $(30 \mathrm{mg} / \mathrm{kg})$. The muscles overlying the cisterna magna were locally anesthetized before reflecting them. A microdrive was used to advance a 30 gauge needle through the cisterna magna. Typically, injections of $100-400 \mu \mathrm{l}(0.5-0.7 \mathrm{mg} / \mathrm{ml})$ were made over an interval of $1-3 \mathrm{~min}$.

Eye movement recording. Eye movements were measured by an infrared light projection technique. The right eye was topically anesthetized with proparacaine hydrochloride. A small suction cup (diameter, $3 \mathrm{~mm}$ ) bearing a light-emitting diode (LED) was affixed to the right eye. The entire suction cup-LED assembly weighed $135 \mathrm{mg}$. The narrow projection beam angle of the LED was aligned with the visual axis and detected with a photosensitive X-Y position detector (United Detector Technology, Hawthorne, CA) fixed relative to the head. The detector had a diameter of $3.8 \mathrm{~cm}$ and provided continuous $\mathrm{X}-\mathrm{Y}$ voltages proportional to the horizontal and vertical position of the incident centroid of infrared light. Eye movements were calibrated by moving the LED on a model of the rabbit eye through a known angular displacement. The system had a sensitivity of $0.2 \mathrm{~min}$ of arc and was linear to within $5 \%$ for eye deviations of $15^{\circ}$ and to $8 \%$ for deviations of $30^{\circ}$ (Barmack, 1981).

\section{Results}

\section{DDRT-PCR identification of changes in retinal transcription} evoked by HOKS

Optokinetic stimulation was used to generate differences in activity of directionally selective ganglion cells in the left and right retinas. DDRT-PCR was used to detect whether long-term differences in activity caused systematic changes in transcription of any retinal genes. After $48 \mathrm{hr}$ of unidirectional HOKS, total RNA was isolated from the central region of each retina and reverse transcribed to cDNA. Differentially transcribed gene products were reamplified and sequenced. Several differentially transcribed gene products were identified (Table 1). Four of these gene products were implicated potentially in the regulation of GABA receptors: (1) ACBP, (2) GABA receptor-associated protein (GABARAP), (3) 14-3-3- $\epsilon$ protein, and (4) 14-3-3- $\theta$ protein. Herein we focus on ACBP.

ACBP, named for its ability to bind thiol esters of coenzyme A, provides a pool of long chain acyl-coenzyme As and transports them from the cytosol to the membrane (Kragelund et al., 1999). ACBP is also known as the diazepam binding inhibitor, because it displaces diazepam at $\mathrm{GABA}_{\mathrm{A}}$ receptors and consequently reduces the efficacy of GABA in evoking inhibition mediated by the $\mathrm{GABA}_{\mathrm{A}}$ receptor (Costa and Guidotti, 1991; Knudsen et al., 1993). Perfusion of cultured motoneurons with $10 \mu \mathrm{M}$ ACBP reduces IPSCs evoked by iontophoretic application of GABA (Bormann et al., 1987, 2000).

\section{ACBP full-length sequence}

Transcripts of ACBP mRNA and of the other mRNAs identified by DDRT-PCR were found in greater abundance in the retina stimulated in the posterior $\rightarrow$ anterior (preferred) direction (Fig. 2). The full-length sequence was obtained by cloning DDRT-PCR gene fragments into a pT7Blue vector and using the cloned sequence to screen a rabbit brain $5^{\prime}$-stretch plus cDNA library (Clontech). The 5' and 3' cDNA end sequences were obtained using a Gene Racer Sequencing kit (Invitrogen). Protein sequences were deduced from full-length cDNAs.

In the rabbit, ACBP consists of 87 aa. ACBP has two potential phosphorylation sites that fit the pattern for protein kinase $\mathrm{C}$ (PKC) phosphorylation and three that fit the pattern for casein kinase phosphorylation (Table $2 A$ ). ACBP is highly conserved in mammals (Table $2 B$ ).

\section{Northern blots for ACBP confirm results from DDRT-PCR}

The optokinetically evoked increases in transcription of ACBP mRNA in a retina stimulated in the preferred direction compared with a retina stimulated in the null direction were confirmed by Northern blot (Fig. 2C). Forty-eight hours of binocular HOKS in the posterior $\rightarrow$ anterior (preferred) direction with respect to the left eye caused a relative increase in transcription of ACBP mRNA in the central retina of the left eye. The transcription of the "housekeeping gene" glyceraldehyde-3-phosphate dehydrogenase was not affected by the HOKS.

\section{Hybridization histochemistry localizes ACBP to Muller glial cells}

Hybridization histochemistry was used to determine specific cells in the retina that express ACBP. Three oligonucleotide probes for rabbit ACBP mRNA were hybridized with histological sections of the retinas in six rabbits: (1) 5'-ACGTCACCCACGGTTGCCTGTTTGTAATGGCTGTA-3', (2) 5' -CCCATCATCTGCAGTATTAGAAAAACAAGGCCTATTGGTTTAG-3' , and (3) 5'-GATTCCGTACTTCTGCTTGAGCTCCTCCACTTTGTCCACGTACGCTC-3'. These corresponded to 132-166, 345-387, and 262308 , respectively, of the full-length rabbit ACBP cDNA sequence (Table 2).

In a retinal whole mount, the $\mathrm{ACBP} 1$ probe labeled regions of the retina that flanked the myelinated nerve fibers that extended from the optic nerve head. The region just inferior to these myelinated nerve fibers was most densely labeled (Fig. 3E). Probes $\mathrm{ACBP} 1$ and $\mathrm{ACBP} 3$ were from the coding region and hybridized in the retina to a region extending from the ganglion cell layer to the inner nuclear layer (Fig. $3 A-D$ ). None of the neuronal cell 

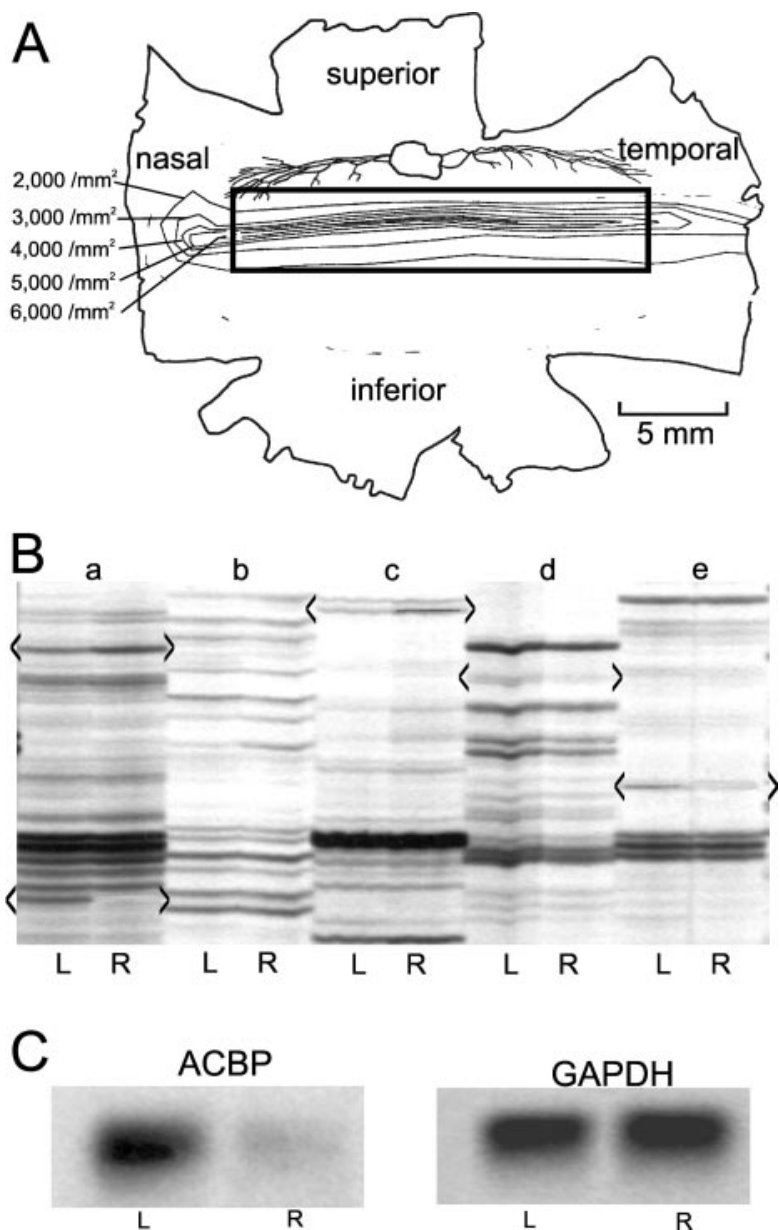

Figure 2. DDRT-PCR. A, A rectangular strip was cut from the neural retina just below the horizontally aligned myelinated fiber band and blood vessels extending from the optic nerve head. This strip included the visual streak, the retinal region of peak ganglion cell density. Ganglion cell isodensity contour lines are indicated (Hughes, 1971). Total RNA was extracted, and mRNAs were reverse transcribed to CDNAs. CDNAs were preferentially amplified using 48 combinations of primer pairs. $B$, Samples from the left and right retinas, amplified by the same set of primers, were run on adjacent lanes of a denaturing gel and separated by electrophoresis. Brackets indicate left $(\mathrm{L})$-right $(\mathrm{R})$ samples that were differentially transcribed during $48 \mathrm{hr}$ of HOKS. C, A Northern blot compared the ACBP mRNA extracted from a pair of retinas, one stimulated in the preferred direction and the other in the null direction. ACBP mRNA increased in the retina stimulated in the preferred direction. GAPDH, glyceraldehyde-3-phosphate dehydrogenase.

types in this region (amacrine cells, ganglion cells, bipolar cells) hybridized with the ACBP probes. Rather, the probes colocalized to Muller glial cells. The probes also hybridized with another glial astrocyte, the Bergman glial cell, in the cerebellum (Fig. $3 F$ ).

\section{Optokinetic stimulation changes retinal ACBP expression: Western blots}

Western blots were used to determine whether changes in retinal transcription of ACBP mRNA led to changes in protein expression. Retinal lysates were prepared and divided into cytosolic and membrane-associated fractions. These fractions were then run on a $15 \%$ SDS gel, using a bacterially expressed ACBP as a control (Fig. $4 A$ ). These blots showed that ACBP is an $\sim 14 \mathrm{kDa}$ protein found as a single band in the cytosol. Membrane-associated ACBP appeared as a double band. One band corresponded to the $14 \mathrm{kDa}$ found in the cytoplasm. A second band, $20 \mathrm{kDa}$, was also observed. When the lysates were run on a $12.5 \%$ urea denaturing gel, the heavier band in the membrane-associated fraction was reduced (Fig. $4 B$ ).

Cytosolic and membrane-associated fractions were compared from the left and right retinas of rabbits receiving $48 \mathrm{hr}$ of HOKS. Cytosolic ACBP expression was greater in the retina (left) that received HOKS in the posterior $\rightarrow$ anterior (preferred) direction, as opposed to the retina (right) that received HOKS in the anterior $\rightarrow$ posterior (null) direction (Fig. 4C). This difference was not evident in the membrane-associated fractions run on the SDS gel but was evident in the bands run on the urea gels (Fig. 4C,D).

The optical densities of the cytosolic fractions from the left and right retinas were measured in five rabbits exposed to $48 \mathrm{hr}$ of HOKS. The optical density of the cytosolic fraction isolated from retinas stimulated in the preferred direction was greater than the optical density of the cytosolic fraction isolated from the retinas stimulated in the null direction $(n=4$; mean, posterior $\rightarrow$ anterior $=64.5 \pm 6.9$; mean, anterior $\rightarrow$ posterior $=$ $35.6 \pm 7.0$; one-tailed $t$ test; $p<0.001$ ).

\section{ACBP localized to Muller cells by immunohistochemistry}

ACBP antisera were used to immunolabel the retina and to further localize cells that expressed ACBP. Muller cells, particularly in the inner plexiform and ganglion cell layers, were immunolabeled by the ACBP antisera. Immunolabeled Muller cell processes extended transversely in the lower part of the outer nuclear layer. Muller cells were clearly identified in retina stained with $1 \%$ toluidine blue (Fig. 5A). Muller cells were immunolabeled by ACBP antibodies (Fig. 5B). The Muller cell foot in the ganglion cell layer was particularly well immunolabeled, frequently obscuring ganglion cell bodies, which were not.

\section{ACBP interacts with $\mathrm{GABA}_{\mathrm{A}} \boldsymbol{\alpha}_{1}$}

In spinal motoneurons, $\mathrm{ACBP}$ reduces the sensitivity of $\mathrm{GABA}_{\mathrm{A}}$ receptors (Bormann, 1991). In the retina, although several transmitter systems may contribute, GABAergic pathways are most clearly linked to direction selectivity. When $\mathrm{GABA}_{\mathrm{A}}$ receptors are blocked, direction selectivity is reduced (Caldwell et al., 1978; Kittila and Massey, 1995, 1997). If ACBP expression and secretion by Muller cells alter the sensitivity of $\mathrm{GABA}_{\mathrm{A}}$ receptors of retinal neurons, then $\mathrm{ACBP}$ should interact with at least one of the $\mathrm{GABA}_{\mathrm{A}}$ receptor subunits.

We used a yeast two-hybrid protocol to test whether ACBP interacted with $\mathrm{GABA}_{\mathrm{A}} \alpha_{1}$. ACBP was linked to the $\mathrm{BD}$, and the $\alpha_{1}$-subunit of $\mathrm{GABA}_{\mathrm{A}} \alpha_{1}$ was linked to the $\mathrm{AD}$ of a reporter gene that expressed $\beta$-galactosidase (Fig. $6 A$ ). The affinity of ACBP for $\mathrm{GABA}_{\mathrm{A}} \alpha_{1}$ brought the $\mathrm{AD}$ and $\mathrm{BD}$ into close proximity and activated transcription of the reporter gene (lexAop) ${ }_{8}$-lac $Z$ (Fig. $6 B)$. No transcription was detected when either $\mathrm{GABA}_{\mathrm{A}} \alpha_{1}$ or ACBP was omitted (Fig. $6 C, D$ ). In a separate negative control, transcription-expression of $\beta$-galactosidase was not detected when two proteins known not to interact, human lamin $\mathrm{C}$ and simian virus 40 (SV40), were coincubated (Fig. 6F). Conversely, transcription was detected when two proteins known to interact, murine p53 and SV40, were coincubated (Fig. 6E). This indicates that the yeast two-hybrid system accurately reported the interaction of $\mathrm{ACBP}$ and $\mathrm{GABA}_{\mathrm{A}} \alpha_{1}$.

The interaction of $\mathrm{GABA}_{\mathrm{A}} \alpha_{1}$ with $\mathrm{ACBP}$ was demonstrated further using a coimmunoprecipitation assay. An antibody to $\mathrm{GABA}_{\mathrm{A}} \alpha_{1}$ was used to immunoprecipitate it from a retinal lysate. Subsequent immunostaining of the immunoprecipitate showed that ACBP was coimmunoprecipitated with $\mathrm{GABA}_{\mathrm{A}} \alpha_{1}$ (Fig. 7A).

Additional evidence of the association of ACBP with $\mathrm{GABA}_{\mathrm{A}} \alpha_{1}$ was obtained using a pull-down assay, in which histidine-tagged 


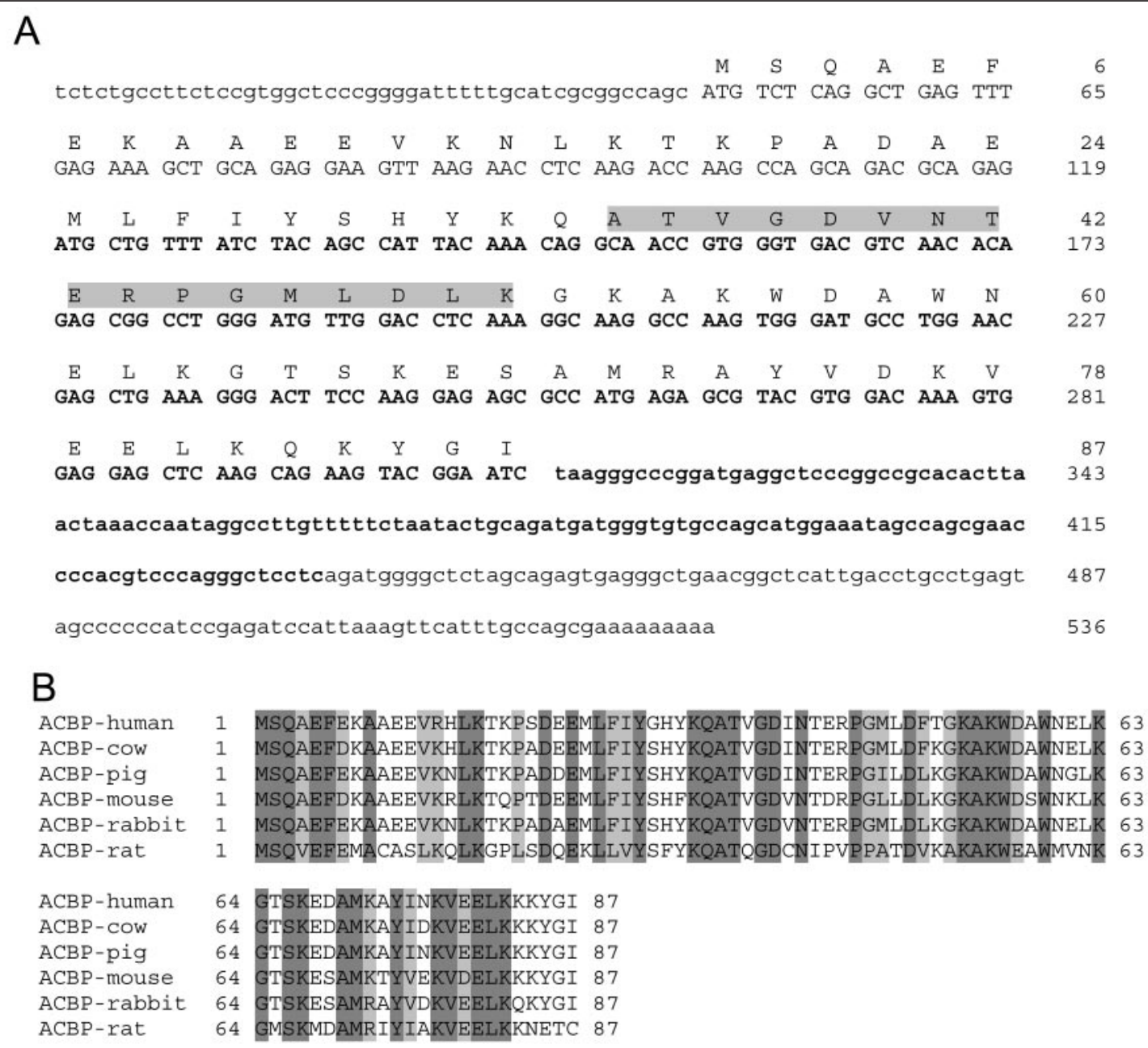
A, A large gene fragment was obtained from the retina by DDRT-PCR (bolded letters). This sequence was expanded using a cDNA stretch library and a GeneRacer kit (Invitrogen). The gray shading indicates the region showing the truncated
form of ACBP, which comprises the ODN. B, The rabbit sequence is compared with ACBP sequences from several other mammals. The dark gray shading indicates complete homology for all species. The light gray shading indicates homologies based on equally charged amino acids.

ACBP was expressed by QNR/K2 cells transfected with the PCDNA 3.1 expression vector containing the histidine-tagged ACBP gene. Western blots of pulled-down proteins were probed with antibodies to ACBP and $\mathrm{GABA}_{\mathrm{A}} \alpha_{1}$ (Fig. 7B). These Western blots had immunoreactive bands to both antibodies, demonstrating an association between $\mathrm{ACBP}$ and $\mathrm{GABA}_{\mathrm{A}} \alpha_{1}$.

\section{Central actions of ACBP}

If $A C B P$ interacts with $\mathrm{GABA}_{\mathrm{A}} \alpha_{1}$, then this interaction should be reflected centrally as well as peripherally. In three rabbits, intravenous injections of $0.5 \mathrm{ml}$ of ACBP $(0.5-1 \mathrm{mg} / \mathrm{ml})$ failed to cause any change in the EEG or in the gain of the vertical vestibuloocular reflex (VVOR). The VVOR was used as a behavioral index of arousal. The gain of the VVOR increases with increased arousal. In two rabbits, intravenous injections of $0.5 \mathrm{ml}$ of ACBP $(0.5-0.8 \mathrm{mg} / \mathrm{ml})$ were combined with coinjections of mannitol $(1.4 \mathrm{M})$ to open the blood-brain barrier. Integrated EEG activity and the gain of the VVOR increased within 2 min and slowly decreased over the next $30 \mathrm{~min}$.

In one rabbit, an intravenous injection of $1 \mathrm{ml}$ of octadecaneuropeptide (ODN) $(0.8 \mathrm{mg} / \mathrm{ml})$, QATVGDVNTERPGMLDLK, a truncated derivative of ACBP, failed to increase cortical activity unless it was also coinjected with mannitol.
In three rabbits, intravenous injections of $0.5 \mathrm{ml}$ of a truncated 6 aa residue GMLDLK, which included the C-terminal lysine of ODN $(0.5-1 \mathrm{mg} / \mathrm{ml})$, increased cortical activity and the gain of VVOR. This effect did not require coadministration of mannitol. These data suggest that although ACBP does not cross the bloodbrain barrier, one or more of its proteolytic products does and excites cortical neurons.

In three rabbits, intracisternal injections of $100-400 \mu \mathrm{l}$ of ACBP $(0.5-0.7 \mathrm{mg} / \mathrm{ml})$ increased cortical activity and the gain of the VVOR (Fig. $8 \mathrm{~A}$ ). Increased cortical activity was quantified by determining the relative duration during which the integrated EEG exceeded the preinjection mean EEG activity by $>2$ SDs. This was normalized for each rabbit during intervals of $2 \mathrm{~min}$. Intracisternal injections of ACBP increased the normalized mean EEG activity by 50\% (Fig. 8B). This ACBP-evoked increase lasted $20 \mathrm{~min}$.

\section{Discussion}

ACBP and other GABA-related mRNAs increased by optokinetic stimulation

We isolated four gene fragments related to GABAergic synaptic transmission. Although we focused on ACBP, the other mRNAs detected by the DDRT-PCR screen might also participate in the regulation of sensitivity of GABAergic signaling pathways. 

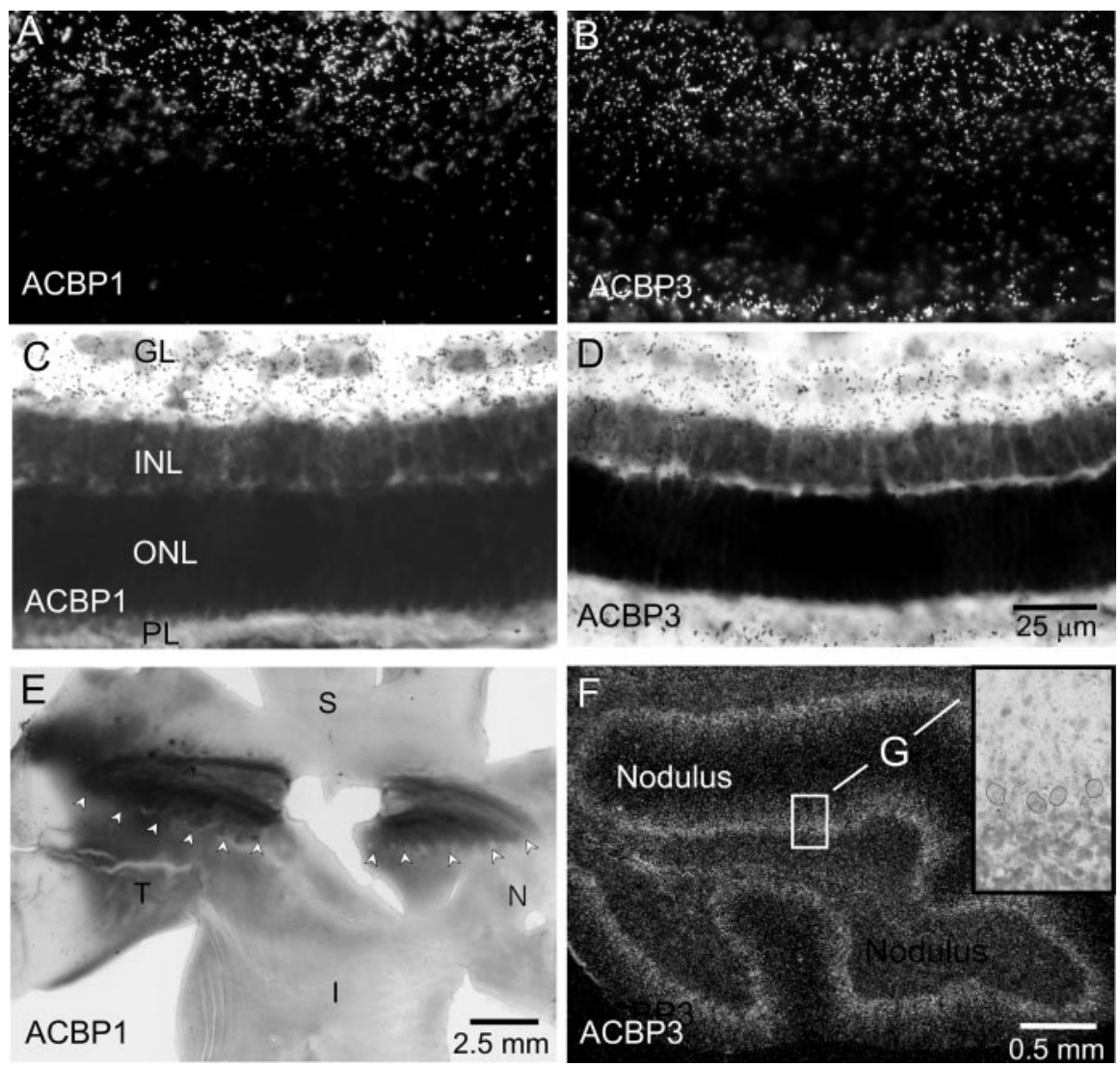

Figure 3. Hybridization histochemistry localizes ACBP mRNA to the inner nuclear, inner plexiform, and ganglion cell layers of the retina. Two oligonucleotide probes for rabbit ACBP mRNA (ACBP1 and ACBP3) were used for hybridization histochemistry. $A$, $B$, Dark-field view of hybridization in the ganglion cell layer and inner nuclear layer of the retina. The probes did not colocalize to either ganglion or amacrine cells. C, D, Bright-field view of the hybridization to the inner nuclear, inner plexiform, and ganglion cell layers. The region of greatest hybridization corresponds to the region of Muller glial cell processes. $E$, Hybridization of probe to the area surrounding the myelinated nerve fibers in a rabbit retinal whole mount. Arrowheads indicate the ventral border of fibers radiating from the optic nerve head. F, A probe (ACBP3) was also applied to a sagittal section of cerebellar nodulus. The probe hybridized with Bergman glial astrocytes. $G$, The inset shows the absence of hybrization with Purkinje cell bodies at higher magnification. Four Purkinje cell bodies are outlined. GL, Ganglion cell layer; INL, inner nuclear layer; ONL, outer nuclear layer; PL, photoreceptor layer; S, superior; T, temporal; N, nasal; I, inferior.

\section{GABA-RAP}

GABA-RAP is a small 117 aa polypeptide that recognizes and binds to the intracellular loop of the $\gamma_{2}$-subunit of the GABA receptor. GABA-RAP does not interact with the $\alpha_{1,2,4-6}$ or $\beta_{1-3}$ subunits of the $\mathrm{GABA}_{\mathrm{A}}$ receptor (Nymann-Andersen et al., 2002). Possibly, it links the $\gamma_{2}$-subunit to microtubules for transport within the cell (Wang et al., 1999; Wang and Olsen, 2000). Although it binds to gephyrin, a protein implicated in the clustering of $\mathrm{GABA}_{\mathrm{A}}$ receptors, GABA-RAP does not colocalize with gephyrin in brain synapses (Kneussel et al., 2000). GABA-RAP promotes clustering of $\mathrm{GABA}_{\mathrm{A}}$ receptors in recombinant cell expression systems, suggesting a role in directing $\mathrm{GABA}_{\mathrm{A}}$ receptors to synapses (Chen et al., 2000). However, the exact role of GABA$\mathrm{RAP}$ in receptor trafficking and synaptic localization remains unknown.

\section{4-3-3 proteins}

Originally named for their migration positions in twodimensional gel electrophoresis of brain extracts, the family of 14-3-3 proteins is highly conserved and acts as adapter or scaffold proteins that bind to and interconnect several proteins involved in signal transduction, cell-cycle regulation, and apoptosis (Aitken, 1996). Isoforms of 14-3-3 interact with $\mathrm{GABA}_{\mathrm{B}}$ receptors
(Couve et al., 2001) as well as PKC- $\gamma$, PKC- $\epsilon$ (Yaffe et al., 1997), PKC- $\theta$ (Meller et al., 1996), PKC- $\zeta$ (Van Der Hoeven et al., 2000), and PKC- $\mu$ (Hausser et al., 1999).

\section{Action of ACBP in retina}

ACBP is one of several retinal gene products, the expression of which is affected by HOKS. It is increased in the retina receiving $\mathrm{HOKS}$ in the preferred direction relative to the retina stimulated in the null direction. If $A C B P$ interacts with $\mathrm{GABA}_{\mathrm{A}}$ receptors localized to dendrites of $\mathrm{ON}$ DSGCs and amacrine cells, then it must be secreted by Muller cells. A secretory role for glia has been demonstrated in cultured cortical astrocytes for atrial natriuretic peptide (Krzan et al., 2003). Cultured Muller glial cells secrete apolipoprotein E (apoE) (Amaratunga et al., 1996) and NGF (Dicou et al., 1994) as well as a factor that induces $\mathrm{M}_{2}$ muscarinic receptor expression in the retina (Belmonte et al., 2000). In intact eyes, apoE is internalized by retinal ganglion cells and transported centrally in the optic nerve. Although the secretion of ACBP from Muller cells has not been measured in vivo, model Muller cells (QNR/K2 cells) maintained in tissue culture release ACBP when depolarized by increases in extracellular $\mathrm{KCl}$ (T. Bilderback, Z. Qian, and N. H. Barmack, unpublished observations).

Once released, ACBP could interact with $\mathrm{GABA}_{\mathrm{A}}$ receptors on ganglion cell dendrites that receive a GABAergic direction-selective signal from Starburst amacrine cell axon terminals (Euler et al., 2002). Amacrine cell axon terminals and ganglion cell dendrites are intertwined with horizontal Muller cell processes in the inner plexiform layer (Dreher et al., 1992), the region of maximal hybridization signal for ACBP mRNA. This suggests the possibility that Muller cells, depolarized locally in the inner plexiform layer by the discharge of GABAergic amacrine cells, secrete ACBP and thereby reduce the sensitivity of $\mathrm{GABA}_{\mathrm{A}}$ receptors on ganglion cell dendrites, providing a local negative feedback loop.

The hypothesized, long-latency feedback loop provided by OKS-evoked transcription, expression, and secretion of ACBP is not the only mechanism by which Muller cells influence GABAergic synaptic transmission at ganglion cells. Muller cells also express high-affinity GABA transporter (GAT) proteins, GAT-1 and GAT-3 (Biedermann et al., 2002). Extracellularly applied GABA is cleared by these GABA transporters within 100 msec. Consequently, GABAergic transmission between amacrine and ganglion cells is regulated by at least two separate mechanisms having different dynamics. Both are dependent on the Muller cell.

A third possible mechanism for the postsynaptic regulation of GABAergic transmission in the retina is represented by altered transcription of GABA-RAP. This protein, expressed by ganglion 

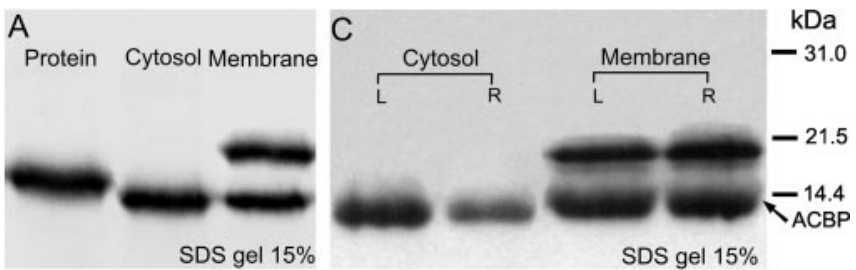

B

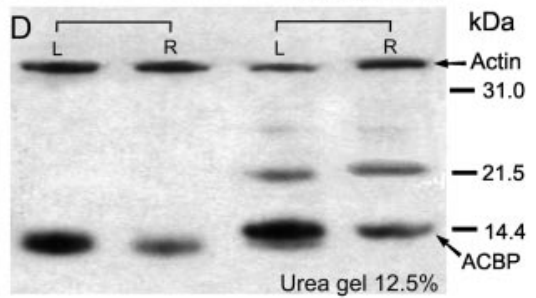

Figure 4. $\quad A C B P$ expression in the retina after $48 \mathrm{hr}$ of HOKS. Retinal lysates were separated into cytosolic and membrane fractions. These fractions were immunoprecipitated. $A$, Western blots were run on a $15 \%$ SDS-PAGE gel and immunolabeled with an antibody to ACBP (chicken host). The membrane fraction appears as a dimer, having two bands at 14.4 and $20 \mathrm{kDa}$. $B$, Immunoprecipitates were also run on a $12.5 \%$ urea gel, reducing the larger of the two membrane bands. C, Samples from the left $(\mathrm{L})$ and right $(\mathrm{R})$ retinas of a rabbit that received optokinetic stimulation for $48 \mathrm{hr}$ were run on a 15\% SDS-PAGE gel. The expression of ACBP in the cytosolic fraction was greater in the left retina, stimulated in the preferred direction, than in the right retina, stimulated in the null direction. $D$, Samples from the same left and right retinas were also run on a $12.5 \%$ urea gel. This gel showed greater expression of ACBP in the left cytosolic fraction and in the lower band of the left membrane fraction. The bands at $40 \mathrm{kDa}$ indicate controls for sample loading using an antibody to actin.
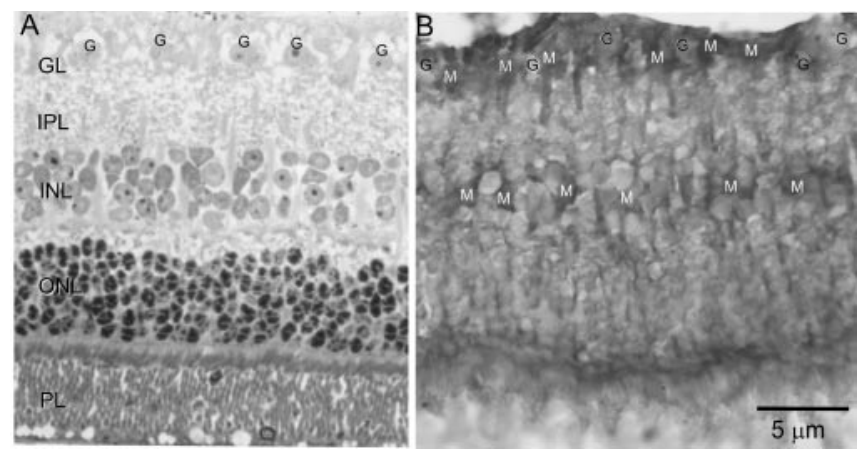

Figure 5. Immunohistochemical localization of ACBP to Muller glial cells. $A$, Normal retina stained with $1 \%$ toluidine blue. $B$, Immunohistochemical staining of retina with ACBP antiserum and the PAP method. G, Ganglion cell; GL, ganglion cell layer; INL, inner nuclear layer; IPL, inner plexiform layer; M, Muller cell; ONL, outer nuclear layer; PL, photoreceptor layer.

cells, could alter the sensitivity of these cells to GABA by regulating the number of $\mathrm{GABA}_{\mathrm{A}}$ receptors inserted into the postsynaptic membrane.

\section{Molecular interactions of ACBP}

In other neural systems, the expression and release of a signaling molecule is associated with its phosphorylation or dephosphorylation. One mechanism by which the signaling molecule PKC is activated is through phosphorylation of specific threonine, serine, and tyrosine residues by other protein kinases (Parekh et al., 2000; Fukunaga et al., 2001; Zheng et al., 2002). ACBP has five potential phosphorylation sites: two threonine sites fit a PKC phosphorylation pattern (42-44 TeR and 65-67 TsK). Two fit a casein kinase-2 (CK2) pattern (36-39 TvgD and 65-68 TskE). One serine site fits a CK2 pattern (2-5 SqaE) (Table 2).

The crystal structure of bovine liver ACBP provides insight into how phosphorylation sites might be distributed in space

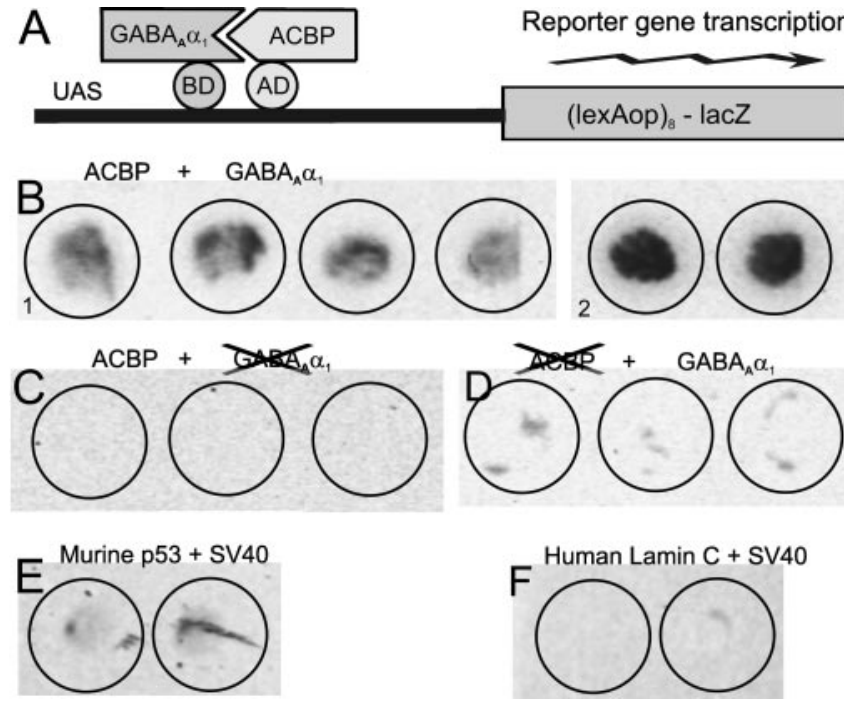

Figure 6. Interaction between $\mathrm{ACBP}$ and $\mathrm{GABA}_{\mathrm{A}} \alpha_{1}$ shown by yeast two-hybrid assay. $A$, Schematic of yeast two-hybrid technique. $A C B P$ is linked to the $A D$. Bacterially expressed $\mathrm{GABA}_{A} \alpha_{1}$ is linked to the $\mathrm{BD}$ on the upstream activation sequence (UAS). The affinity of $A C B P$ for $\mathrm{GABA}_{A} \alpha_{1}$ brings the $\mathrm{AD}$ and $\mathrm{BD}$ into close proximity and activates transcription of the reporter gene (lexAop) $)_{8}$-lacZ. $B$, Two separate tests of interaction yielded positive results (transcription of the reporter gene). $C$, Negative control; no transcription was detected when $\mathrm{GABA}_{A} \alpha_{1}$ was omitted. D, Negative control; no transcription was detected when ACBP was omitted. $E$, Positive control; transcription was detected when two proteins known to interact, murine $\mathrm{p} 53$ and SV40, were coincubated. $F$, Negative control; transcription was not detected when two proteins known not to interact, human lamin C and SV40, were coincubated.

(Andersen and Poulsen, 1992). Only 6 of 87 aa of rabbit retinal ACBP differ from those of the bovine liver ACBP. In five of six of these, the discrepant amino acids share homologies based on charge. In crystalline ACBP, the five threonine and serine residues are located close to the protein exterior, making these sites available for phosphorylation.

ACBP may interact with other transduction molecules such as PKC and CK2, major serine-threonine kinase families, capable of phosphorylating specific sites on ACBP. Several PKC isoforms are expressed in the retina. PKC- $\alpha$ is found in bipolar cells and photoreceptor outer segments (Cuenca et al., 1990; Suzuki and Kaneko, 1990; Osborne and Barnett, 1992; Udovichenko et al., 1993). PKC- $\beta$ and PKC- $\gamma$ are expressed by bipolar cells, ganglion cells, and amacrine cells (Negishi et al., 1988; Osborne and Barnett, 1992; Kolb et al., 1993). PKC- $\delta$ is expressed by Muller cells (Osborne et al., 1994, 1995). A variety of responses have been ascribed to PKC, including modulation of GABA receptor sensitivity (Wood et al., 1997). Two of the subunits of the $\mathrm{GABA}_{\mathrm{A}}$ receptor, $\beta$ and $\gamma_{2}$, also contain putative PKC phosphorylation sites (Krishek et al., 1994). $\mathrm{GABA}_{\mathrm{A}}$ receptor channel function may be downregulated by PKC (Kellenberger et al., 1992; Leidenheimer et al., 1992, 1993; Lin et al., 1994). PKC activity can itself be modulated by the action of 14-3-3 isoforms, and these interactions may be isoform specific (Robinson et al., 1994; Acs et al., 1995; Aitken et al., 1995).

CK2 is a ubiquitous serine threonine kinase that is highly conserved, suggesting that it plays an important role. CK2 is more abundant in the brain than in any other tissue. It has $>200$ substrates (Sarno et al., 2002). Many substrates are found in synaptic and nuclear compartments and have roles in development, neuritogenesis, synaptic transmission, synaptic plasticity, information storage, and survival (Blanquet, 2000). In the retina, CK2 is 


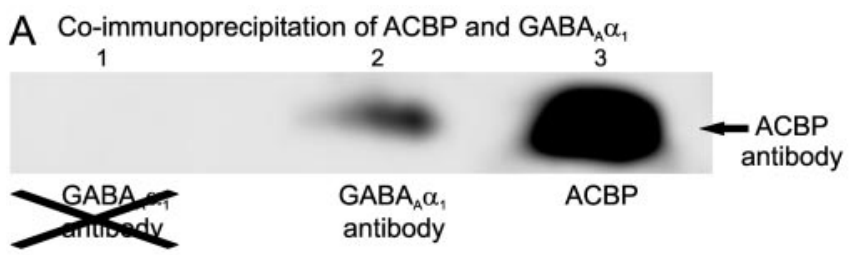

B Association of His-tagged ACBP with $\mathrm{GABA}_{A} \alpha_{1}$

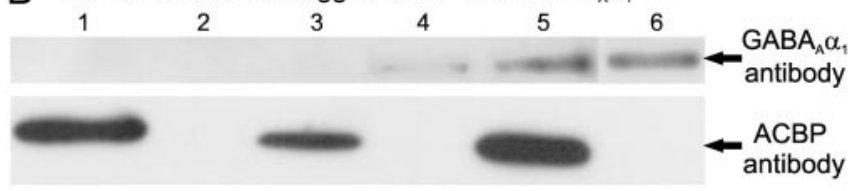

Figure 7. Coimmunoprecipitation of $A C B P$ from rabbit brain lysate with $\mathrm{GABA}_{\mathrm{A} \alpha 1} \cdot A, \mathrm{ACBP}$ was coimmunoprecipitated from a rabbit brain lysate along with $\mathrm{GABA}_{A} \alpha_{1}$ using antibody to $\mathrm{GABA}_{A} \alpha_{1}$. Lane 1, Rabbit brain lysate was run as a control without immunoprecipitation by antibody to $\mathrm{GABA}_{A} \alpha_{1}$. Lane 2, GABA $\alpha_{A}$ and ACBP were coimmunoprecipitated from rabbit brain lysate by an antibody to $G_{A B A_{A}} \alpha_{1}$. Lane 3 , Bacterially expressed $A C B P$ was run as a control. The portion of the blot identified by the antibody to $\mathrm{GABA}_{A} \alpha_{1}$ is not presented, because it was complicated by the migration of the heavy chain of $\mathrm{GABA}_{A} \alpha_{1}$ antibody to the same position as $G A B A_{A} \alpha_{1} \cdot B$, Histidine (His)-tagged ACBP, expressed by QNR/K2 cells, was purified with a column of His-binding beads. The purified His-tagged ACBP was incubated with rabbit brain lysates mixed with His-binding beads. The beads were separated by centrifugation and washed. His-tagged $A C B P$ and the proteins with which it interacted were eluted and run on a Western blot. GABA $\alpha_{A} \alpha_{1}$ associated with the His-tagged ACBP. The top half of the blot was probed with an antibody to $G A B A_{A} \alpha_{1}$. The bottom half was probed with an antibody to ACBP. Lane 1, Bacterially expressed His-tagged ACBP was run as a control. Lane 2, Lysate from untransfected QNR/K2 cells was coincubated with His-binding beads without rabbit brain lysate. Lane 3, Lysate from QNR/K2 cells transfected with His-tagged ACBP gene was incubated with His binding beads. Lane 4, Rabbit brain lysate was coincubated with His-binding beads without His-tagged ACBP. Lane 5, Rabbit brain lysate was coincubated with His-tagged ACBP and Hisbinding beads. Lane 6, A positive control for $\mathrm{GABA}_{A} \alpha_{1}$ was prepared from a microsomal fraction of rat brain. This fraction was not incubated with QNR/K2 cells transfected with the His-tagged ACBP gene. Nonspecific binding of $G A B A_{A} \alpha$ to the His beads is evident in lane 4 . However, the optical density of the specific band in lane 5 is $10 \times$ greater than that of the nonspecific band in lane 4.

found in rod photoreceptors, in which it phosphorylates a cGMP-gated channel (Warren and Molday, 2002).

\section{Action of ACBP and its truncated forms on the CNS}

Digestion of ACBP with trypsin yields an ODN that includes amino acid residues 34-51 (Table 2). The ODN segment of ACBP is located on the exterior of the protein. ODN is pharmacologically active and has the sequence QATVGDVNTERPGMLDLK. ODN displaces benzodiazepines from binding sites on neurons and glial cells with a binding affinity similar to that of ACBP (Bender and Hertz, 1986). ODN decreases pentobarbitalinduced sleep in mice, suggesting that ODN modulates $\mathrm{GABA}_{\mathrm{A}}$ responses (Dong et al., 1999).

ODN has two phosphorylation sites, one for PKC and one for $\mathrm{CK} 2$. The C-terminal region of ODN is critical. Amidification of the C-terminal lysine eliminates its pharmacological activity. This raises the question of whether phosphorylation of one or more of the sites on ACBP is either necessary or sufficient for its interaction with $\mathrm{GABA}_{\mathrm{A}} \alpha_{1}$. An alternative possibility is that the interaction of ACBP with $\mathrm{GABA}_{\mathrm{A}} \alpha_{1}$ depends on the lysine at position 51 rather than the phosphorylation of either the PKC or CK2 sites. A third possibility is that the first two possibilities are both correct. The pharmacological activity of intact ACBP may depend on the phosphorylation sites to orient the protein correctly so that lysine-51 is exposed. In the truncated ODN, Lys-51 may be exposed without phosphorylation.
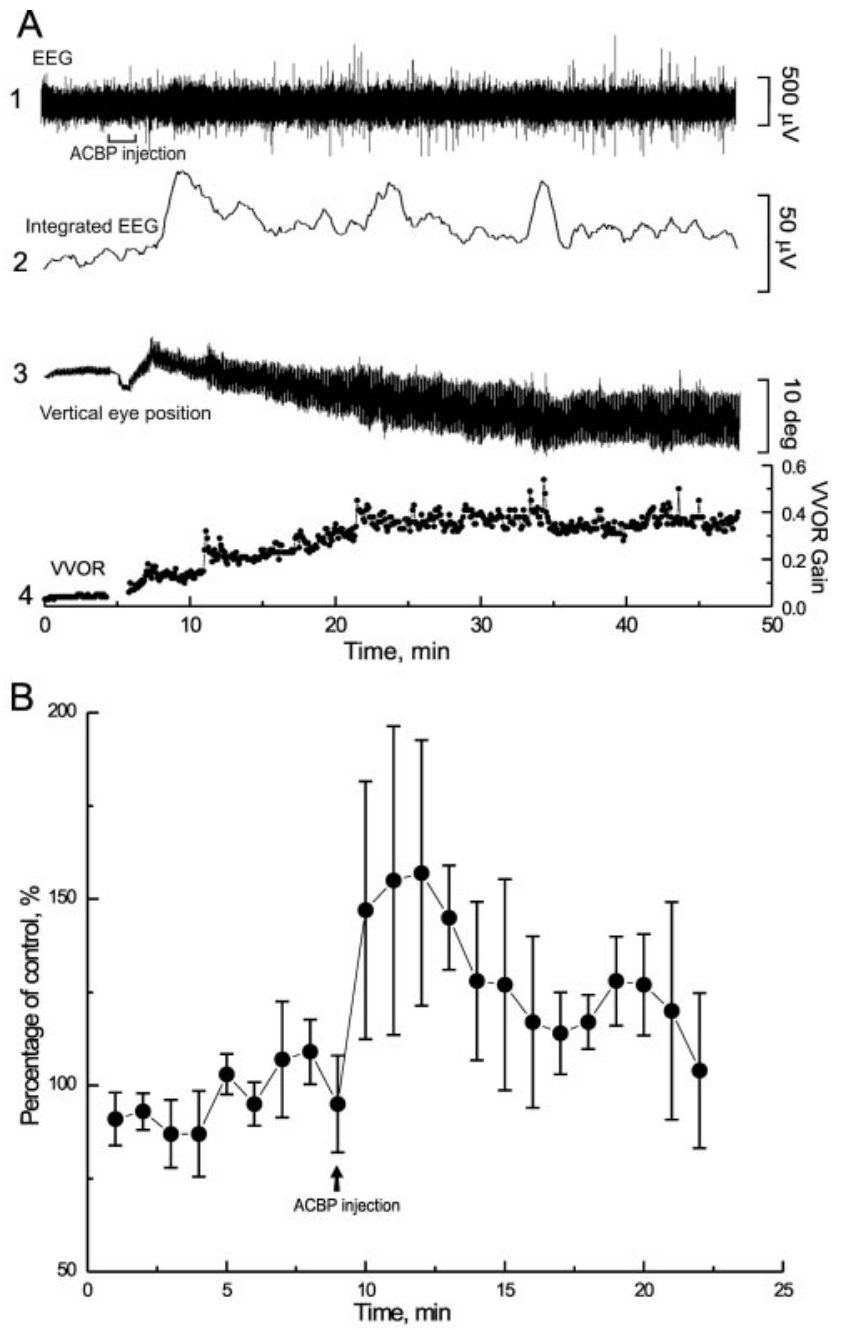

Figure 8. Intracisternal injection of ACBP increases EEG activity and increases gain of vertical vestibulo-ocular reflex. An intracisternal cannula was inserted in a lightly anesthetized rabbit (ketamine hydrochloride, $30 \mathrm{mg} / \mathrm{kg}$ ). Background EEG was maintained constant during sinusoidal roll-tilt vestibular stimulation about the longitudinal axis $\left(20^{\circ}, 0.2 \mathrm{~Hz}\right)$. ACBP was intracisternally injected ( $400 \mu \mathrm{l}, 0.7 \mathrm{mg} / \mathrm{ml}, 2 \mathrm{~min}$ ). The intracisternal injection of ACBP caused an increase in EEG activity and an increase in gain of the VVOR. A1, An EEG trace was obtained from chronically implanted cortical electrode. The duration of the intracisternal injection is indicated by the bar. $A 2$, The EEG was full-wave rectified and integrated. $A 3$, Vertical eye movements were recorded with a photoelectric technique. A4, Gain of the VVOR was calculated for each cycle of stimulation. $B$, Three rabbits received intracisternal injections of ACBP (100-400 $\mu l, 0.7 \mathrm{mg} / \mathrm{ml}, 2 \mathrm{~min}$ ). Normalized mean change in EEG activity was plotted for the group. The injection onset is indicated by the arrow.

The C-terminal region of ODN is critical. Amidification of the C-terminal lysine eliminates all pharmacological activity (Berkovich et al., 1990). Three smaller peptides, consisting of $6-8$ aa, all of which include the $\mathrm{C}$-terminal lysine, have binding characteristics similar to that of ODN. The 8 aa peptide has an efficacy equal to the full-length ACBP in modulating glucose-stimulated secretion of insulin from rat pancreatic islets (Borboni et al., 1991).

In the present experiment, a 6 aa peptide containing the C-terminal lysine crossed the blood-brain barrier and increased EEG activity. Because plasma levels of ACBP and its truncated forms are elevated in epileptic patients (Ferrarese et al., 1998), it is possible that some forms of epilepsy may be triggered either by defects in the blood-brain barrier or by increased plasma concentration of truncated forms of ACBP. 


\section{References}

Acs P, Szallasi Z, Kazanietz MG, Blumberg PM (1995) Differential activation of PKC isozymes by 14-3-3 zeta protein. Biochem Biophys Res Commun 216:103-109.

Aitken A (1996) 14-3-3 and its possible role in coordinating multiple signalling pathways. Trends Cell Biol 6:341-347.

Aitken A, Howell S, Jones D, Madrazo J, Martin H, Patel Y, Robinson K (1995) Post-translationally modified 14-3-3 isoforms and inhibition of protein kinase C. Mol Cell Biochem 149-150:41-49.

Alley K, Baker R, Simpson JI (1975) Afferents to the vestibulo-cerebellum and the origin of the visual climbing fibers in the rabbit. Brain Res 98:582-589.

Amaratunga A, Abraham CR, Edwards RB, Sandell JH, Schreiber BM, Fine RE (1996) Apolipoprotein E is synthesized in the retina by Muller glial cells, secreted into the vitreous, and rapidly transported into the optic nerve by retinal ganglion cells. J Biol Chem 271:5628-5632.

Andersen KV, Poulsen FM (1992) Three-dimensional structure in solution of acyl-coenzyme A binding protein from bovine liver. J Mol Biol 226:1131-1141.

Barlow HB, Levick WR (1965) The mechanism of directionally selective units in rabbit's retina. J Physiol (Lond) 178:477-504.

Barmack NH (1981) A comparison of the horizontal and vertical vestibuloocular reflexes of the rabbit. J Physiol (Lond) 314:547-564.

Barmack NH, Nelson BJ (1987) Influence of long-term optokinetic stimulation on eye movements of the rabbit. Brain Res 437:111-120.

Barmack NH, Young WSI (1990) Optokinetic stimulation increases corticotropin-releasing factor mRNA in inferior olivary neurons of rabbits. J Neurosci 10:631-640.

Barmack NH, Errico P, Ferraresi A, Fushiki H, Pettorossi VE, Yakhnitsa V (2002) Cerebellar nodulectomy impairs spatial memory of vestibular and optokinetic stimulation in rabbits. J Neurophysiol 87:962-975.

Belmonte KE, McKinnon LA, Nathanson NM (2000) Developmental expression of muscarinic acetylcholine receptors in chick retina: selective induction of M2 muscarinic receptor expression in ovo by a factor secreted by Muller glial cells. J Neurosci 20:8417-8425.

Bender A, Hertz L (1986) Octadecaneuropeptide (ODN; "anxiety peptide") displaces diazepam more potently from astrocytic than from neuronal binding sites. Eur J Pharmacol 132:335-336.

Berkovich A, McPhie P, Campagnone M, Guidotti A, Hensley P (1990) A natural processing product of rat diazepam binding inhibitor, triakontatetraneuropeptide (diazepam binding inhibitor 17-50) contains an alpha-helix, which allows discrimination between benzodiazepine binding site subtypes. Mol Pharmacol 37:164-172.

Biedermann B, Bringmann A, Reichenbach A (2002) High-affinity GABA uptake in retinal glial (Muller) cells of the guinea pig: electrophysiological characterization, immunohistochemical localization, and modeling of efficiency. Glia 39:217-228.

Blanquet PR (2000) Casein kinase 2 as a potentially important enzyme in the nervous system. Prog Neurobiol 60:211-246.

Borboni P, Condorelli L, DeStafanis P, Sesti G, Lauro R (1991) Modulation of insulin secretion by diazepam binding inhibitor and its processing products. Neuropharmacology 30:1399-1403.

Bormann J (1991) Electrophysiological characterization of diazepam binding inhibitor (DBI) on $\mathrm{GABA}_{\mathrm{A}}$ receptors. Neuropharmacology 30:1387-1389.

Bormann J (2000) The "ABC" of GABA receptors. Trends Pharmacol Sci 21:16-19.

Bormann J, Hamill OP, Sakmann B (1987) Mechanism of anion permeation through channels gated by glycine and gamma-aminobutyric acid in mouse cultured spinal neurones. J Physiol (Lond) 385:243-286.

Caldwell JH, Daw NW, Wyatt HJ (1978) Effects of picrotoxin and strychnine on rabbit retinal ganglion cells: lateral interactions for cells with more complex receptive fields. J Physiol (Lond) 276:277-298.

Chen L, Wang HB, Vicini S, Olsen RW (2000) The gamma-aminobutyric acid type $A\left(G_{A B A}\right)$ receptor-associated protein (GABARAP) promotes $\mathrm{GABA}_{\mathrm{A}}$ receptor clustering and modulates the channel kinetics. Proc Natl Acad Sci USA 97:11557-11562.

Chien C-T, Bartel PL, Sternglanz R, Fields S (1991) The two-hybrid system: a method to identify and clone genes for proteins that interact with a protein of interest. Proc Natl Acad Sci USA 88:9578-9582.

Choudhury BP (1981) Ganglion cell distribution in the albino rabbit's retina. Exp Neurol 72:638-644.
Collewijn H (1975) Direction-selective units in the rabbit's nucleus of the optic tract. Brain Res 100:489-508.

Costa E, Guidotti A (1991) Diazepam binding inhibitor (DBI): a peptide with multiple biological actions. Life Sci 49:325-344.

Couve A, Kittler JT, Uren JM, Calver AR, Pangalos MN, Walsh FS, Moss SJ (2001) Association of GABA(B) receptors and members of the 14-3-3 family of signaling proteins. Mol Cell Neurosci 17:317-328.

Cuenca N, Fernandez E, Kolb H (1990) Distribution of immunoreactivity to protein kinase $\mathrm{C}$ in the turtle retina. Brain Res 532:278-287.

Dicou E, Nerriere V, Naud MC, Dekozak Y (1994) NGF involvement in ocular inflammation: secretion by rat resident retinal cells. NeuroReport 6:26-28.

Dong E, Matsumoto K, Tohda M, Watanabe H (1999) Involvement of diazepam binding inhibitor and its fragment octadecaneuropeptide in social isolation stress-induced decrease in pentobarbital sleep in mice. Life Sci 64:1779-1784.

Dreher Z, Robinson SR, Distler C (1992) Muller cells in vascular and avascular retinae: a survey of seven mammals. J Comp Neurol 323:59-80.

Euler T, Detwiler PB, Denk W (2002) Directionally selective calcium signals in dendrites of starburst amacrine cells. Nature 418:845-852.

Ferrarese C, Cogliati T, Tortorella R, Zucca C, Bogliun G, Beghi E, Passoni D, Zoia C, Begni B, Airoldi L, Alho H, Frattola L (1998) Diazepam binding inhibitor (DBI) in the plasma of pediatric and adult epileptic patients. Epilepsy Res 29:129-134.

Fried SI, Munch TA, Werblin FS (2002) Mechanisms and circuitry underlying directional selectivity in the retina. Nature 420:411-414.

Fukunaga M, Oka M, Ichihashi M, Yamamoto T, Matsuzaki H, Kikkawa U (2001) UV-induced tyrosine phosphorylation of PKC delta and promotion of apoptosis in the HaCaT cell line. Biochem Biophys Res Commun 289:573-579.

Giolli RA, Blanks RHI, Torigoe Y, Williams DD (1985) Projections of medial terminal accessory optic nucleus, ventral tegmental nuclei, and substantia nigra of rabbit and rat as studied by retrograde axonal transport of horseradish peroxidase. J Comp Neurol 232:99-116.

Giolli RA, Torigoe Y, Blanks RHI, McDonald HM (1988) Projections of the dorsal and lateral terminal accessory optic nuclei and of the interstitial nucleus of the superior fasciculus (posterior fibers) in the rabbit and rat. J Comp Neurol 277:608-620.

Hausser A, Storz P, Link G, Stoll H, Liu YC, Altman A, Pfizenmaier K, Johannes FJ (1999) Protein kinase C mu is negatively regulated by 14-3-3 signal transduction proteins. J Biol Chem 274:9258-9264.

Hughes A (1971) Topographical relationships between the anatomy and physiology of the rabbit visual system. Doc Ophthalmol 30:33-159.

Kellenberger S, Malherbe P, Sigel E (1992) Function of the alpha 1 beta 2 gamma $2 \mathrm{~S}$ gamma-aminobutyric acid type A receptor is modulated by protein kinase $\mathrm{C}$ via multiple phosphorylation sites. J Biol Chem 267:25660-25663.

Kittila CA, Massey SC (1995) Effect of ON pathway blockade on directional selectivity in the rabbit retina. J Neurophysiol 73:703-712.

Kittila CA, Massey SC (1997) Pharmacology of directionally selective ganglion cells in the rabbit retina. J Neurophysiol 77:675-689.

Kneussel M, Haverkamp S, Fuhrmann JC, Wang H, Wassle H, Olsen RW, Betz H (2000) The gamma-aminobutyric acid type A receptor (GABAAR)-associated protein GABARAP interacts with gephyrin but is not involved in receptor anchoring at the synapse. Proc Natl Acad Sci USA 97:8594-8599.

Knudsen J, Mandrup S, Rasmussen JT, Andreasen PH, Poulsen F, Kristiansen K (1993) The function of acyl-CoA-binding protein (ACBP)/diazepam binding inhibitor (DBI). Mol Cell Biochem 123:129-138.

Kolb H, Zhang L, Dekorver L (1993) Differential staining of neurons in the human retina with antibodies to protein kinase C isozymes. Vis Neurosci 10:341-351.

Kragelund BB, Knudsen J, Poulsen FM (1999) Acyl-coenzyme A binding protein (ACBP). Biochim Biophys Acta 1441:150-161.

Krishek BJ, Xie X, Blackstone C, Huganir RL, Moss SJ, Smart TG (1994) Regulation of $\mathrm{GABA}_{\mathrm{A}}$ receptor function by protein kinase $\mathrm{C}$ phosphorylation. Neuron 12:1081-1095.

Krzan M, Stenovec M, Kreft M, Pangrsic T, Grilc S, Haydon PG, Zorec R (2003) Calcium-dependent exocytosis of atrial natriuretic peptide from astrocytes. J Neurosci 23:1580-1583.

Laemmli UK (1970) Cleavage of structural proteins during the assembly of the head of bacteriophage T4. Nature 227:680-685. 
Leidenheimer NJ, McQuilkin SJ, Hahner LD, Whiting P, Harris RA (1992) Activation of protein kinase $\mathrm{C}$ selectively inhibits the gammaaminobutyric acidA receptor: role of desensitization. Mol Pharmacol 41:1116-1123.

Leidenheimer NJ, Whiting PJ, Harris RA (1993) Activation of calciumphospholipid-dependent protein kinase enhances benzodiazepine and barbiturate potentiation of the $\mathrm{GABA}_{\mathrm{A}}$ receptor. J Neurochem 60:1972-1975.

Liang P, Pardee AB (1992) Differential display of eukaryotic messenger RNA by means of the polymerase chain reaction. Science 257:967-970.

Lin G, McCormick JI, Johnstone RM (1994) Differentiation of two classes of "A" system amino acid transporters. Arch Biochem Biophys 312:308-315.

Meller N, Liu YC, Collins TL, Bonnefoy-Berard N, Baier G, Isakov N, Altman A (1996) Direct interaction between protein kinase $C$ theta (PKC theta) and 14-3-3 tau in T cells: 14-3-3 overexpression results in inhibition of PKC theta translocation and function. Mol Cell Biol 16:5782-5791.

Mustari MJ, Fuchs A, Kaneko CRS, Robinson FR (1994) Anatomical connections of the primate pretectal nucleus of the optic tract. J Comp Neurol 349:111-128.

Negishi K, Kato S, Teranishi T (1988) Dopamine cells and rod bipolar cells contain protein kinase C-like immunoreactivity in some vertebrate retinas. Neurosci Lett 94:247-252.

Nymann-Andersen J, Wang HB, Chen L, Kittler JT, Moss SJ, Olsen RW (2002) Subunit specificity and interaction domain between GABA(A) receptor-associated protein (GABARAP) and $\mathrm{GABA}_{\mathrm{A}}$ receptors. J Neurochem 80:815-823.

Orbach MJ, Sachs MS, Yanofsky C (1990) The neuospora crassa arg-2 locus: structure and expression of the gene encoding the small subunit of arginine-specific carbamoyl phosphate synthetase. J Biol Chem 265:10981-10987.

Osborne NN, Barnett NL (1992) An intraocular injection of kainate induces expression of c-fos-like protein and activation of protein kinase $\mathrm{C}$ (alpha) in specific rabbit retinal neurones. Brain Res Mol Brain Res 15:108-112.

Osborne NN, Wood J, Groome N (1994) The occurrence of three calciumindependent protein kinase $\mathrm{C}$ subspecies $(\delta, \epsilon$ and $\zeta)$ in retina of different species. Brain Res 637:156-162.

Osborne NN, Wood J, Muller A (1995) The influence of experimental ischaemia on protein kinase $\mathrm{C}$ and the GABAergic system in the rabbit retina. Neuropharmacology 34:1279-1288.

Oyster CW, Simpson JI, Takahashi ES, Soodak RE (1980) Retinal ganglion cells projecting to the rabbit accessory optic system. J Comp Neurol 190:49-61.

Parekh DB, Ziegler W, Parker PJ (2000) Multiple pathways control protein kinase C phosphorylation. EMBO J 19:496-503.

Pettorossi VE, Errico P, Ferraresi A, Barmack NH (1999) Optokinetic and vestibular stimulation determines the spatial orientation of negative optokinetic afternystagmus in the rabbit. J Neurosci 19:1524-1531.

Robinson K, Jones D, Patel Y, Martin H, Madrazo J, Martin S, Howell S, Elmore M, Finnen MJ, Aitken A (1994) Mechanism of inhibition of protein kinase $\mathrm{C}$ by 14-3-3 isoforms. 14-3-3 isoforms do not have phospholipase A2 activity. Biochem J 299:853-861.

Sarno S, Moro S, Meggio F, Zagotto G, Dal Ben D, Ghisellini P, Battistutta R, Zanotti G, Pinna LA (2002) Toward the rational design of protein kinase casein kinase-2 inhibitors. Pharmacol Ther 93:159-168.

Schmidt M, Schiff D, Bentivoglio M (1995) Independent efferent populations in the nucleus of the optic tract: an anatomical and physiological study in rat and cat. J Comp Neurol 360:271-285.

Simpson JI, Leonard CS, Soodak RE (1988) The accessory optic system: analyzer of self-motion. Ann NY Acad Sci 545:170-179.

Soodak RE, Simpson JI (1988) The accessory optic system of rabbit. I. Basic visual response properties. J Neurophysiol 60:2037-2054.

Suzuki S, Kaneko A (1990) Identification of bipolar cell subtypes by protein kinase C-like immunoreactivity in the goldfish retina. Vis Neurosci 5:223-230.

Terasawa K, Otani K, Yamada J (1979) Descending pathways of the nucleus of the optic tract in the rat. Brain Res 173:405-417.

Udovichenko IP, Cunnick J, Gonzales K, Takemoto DJ (1993) Phosphorylation of bovine rod photoreceptor cyclic GMP phosphodiesterase. Biochem J 295:49-55.

Van Der Hoeven PC, Van Der Wal JC, Ruurs P, Van Dijk MC, Van Blitterswijk J (2000) 14-3-3 isotypes facilitate coupling of protein kinase C-zeta to Raf-1: negative regulation by 14-3-3 phosphorylation. Biochem J 345:297-306.

Wang H, Olsen RW (2000) Binding of the GABA(A) receptor-associated protein (GABARAP) to microtubules and microfilaments suggests involvement of the cytoskeleton in GABARAPGABA ${ }_{\mathrm{A}}$ receptor interaction. J Neurochem 75:644-655.

Wang H, Bedford FK, Brandon NJ, Moss SJ, Olsen RW (1999) GABA(A)receptor-associated protein links $\mathrm{GABA}(\mathrm{A})$ receptors and the cytoskeleton. Nature 397:69-72.

Warren R, Molday RS (2002) Regulation of the rod photoreceptor cyclic nucleotide-gated channel. Adv Exp Med Biol 514:205-223.

Wood JP, McCord RJ, Osborne NN (1997) Retinal protein kinase C. Neurochem Int 30:119-136.

Yaffe MB, Rittinger K, Volinia S, Caron PR, Aitken A, Leffers H, Gamblin SJ, Smerdon SJ, Cantley LC (1997) The structural basis for 14-3-3: phosphopeptide binding specificity. Cell 91:961-971.

Zheng XM, Resnick RJ, Shalloway D (2002) Mitotic activation of proteintyrosine phosphatase alpha and regulation of its Src-mediated transforming activity by its sites of protein kinase $\mathrm{C}$ phosphorylation. J Biol Chem 277:21922-21929. 